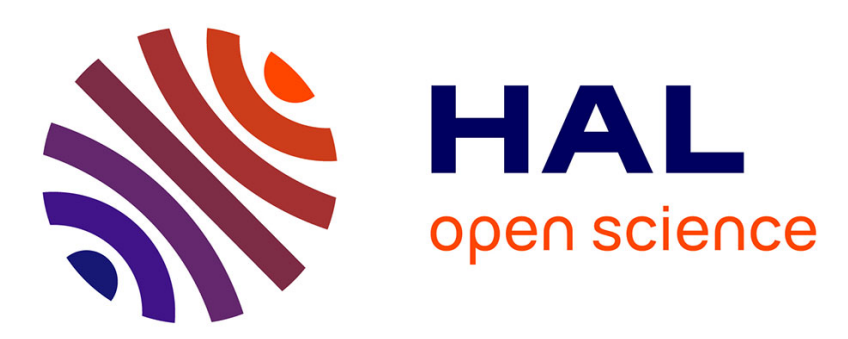

\title{
Comment on "Performance of CNT-water nanofluid as coolant fluid in shell and tube intercooler of a LPG absorber tower"
}

\author{
P. Estellé
}

\section{- To cite this version:}

P. Estellé. Comment on "Performance of CNT-water nanofluid as coolant fluid in shell and tube intercooler of a LPG absorber tower". International Journal of Heat and Mass Transfer, 2016, 103, pp.1378-1379. 10.1016/j.ijheatmasstransfer.2016.08.041 . hal-01358955

\section{HAL Id: hal-01358955 \\ https://hal.science/hal-01358955}

Submitted on 2 Sep 2016

HAL is a multi-disciplinary open access archive for the deposit and dissemination of scientific research documents, whether they are published or not. The documents may come from teaching and research institutions in France or abroad, or from public or private research centers.
L'archive ouverte pluridisciplinaire HAL, est destinée au dépôt et à la diffusion de documents scientifiques de niveau recherche, publiés ou non, émanant des établissements d'enseignement et de recherche français ou étrangers, des laboratoires publics ou privés. 


\title{
Comment on "Performance of CNT-water nanofluid as coolant fluid in shell and tube intercooler of a LPG absorber tower"
}

\author{
P. Estellé * \\ LGCGM, Equipe Matériaux et Thermo-Rhéologie, Université Rennes 1, France
}

\begin{abstract}
* Author to whom correspondence should be addressed.
Electronic mail: patrice.estelle@univ-rennes1.fr

IUT de Rennes, 3 rue du Clos Courtel, BP 90422,

35704 Rennes Cedex 7, France

Tel: +33 (0) 23234200

Fax: +33(0) 223234051
\end{abstract}

\section{Letter to the Editor}

Recently, Hosseini et al. [1] investigated from simulations the potential of CNT-water based nanofluids as coolants in an industrial shell and tube heat exchanger. This study is of interest as the main goal is to demonstrate efficiency of nanofluids in real industrial application. The simulations were performed considering thermophysical properties of CNTwater-based nanofluids we reported earlier in [2,3], except for viscosity and this latter point requires clarifications.

So, for viscosity, the authors considered the model so-called proposed by Wang et al. [4]. First, this model which relates the viscosity of nanofluid $\mu_{n f}$ to the viscosity of base fluid $\mu_{n f}$ and the nanoparticle volume fraction $\phi$, presented in eq. (1) (the equation is referred to same equation number in [1]), was effectively proposed by Maiga et al. [5]. Then, this model was defined for $\mathrm{Al}_{2} \mathrm{O}_{3}$ nanoparticles which are spherical in form.

$$
\mu_{n f}=\mu_{b f}\left(1+7.3 \phi+123 \phi^{2}\right)
$$

Consequently, the model cannot be used with nanotubes due to nature and form of these nanoparticles. Also, following nanoparticle content, CNT nanofluids are shear-thinning so that viscosity depends on shear rate. This is evidenced in Figure 1, where this model is 
plotted against nanotube volume fraction and compared with experimental data extracted from [2]. Figure 1 clearly shows that the model largely underpredicts the relative viscosity enhancement of nanofluids, in particular for volume fraction higher than $0.111 \%$ and whatever the shear rate considered.

This choice is also questionable as viscosity data of CNT-water based nanofluids studied in [1] are also presented and available in [2], as reported in Figure 1. In addition, we considered in [2] that viscosity enhancement of nanofluids can be predicted by a simple empirical and linear model independently of shape and dispersion state of nanoparticles within the range of volume fraction, independently also of temperatures studied. This model is depicted by equation (2) where $\mathrm{C}_{\mu}$ is defined as viscosity enhancement coefficient. The values of $\mathrm{C}_{\mu}$ following the shear rate are also reported in [2]. This could be easily implemented in simulation software.

$$
\mu_{n f} \approx \mu_{b f}\left(1+C_{\mu} \phi\right)
$$

A more comprehensive viscosity model, mainly valid for high shear rate, was also proposed in [6] taking into account a larger range of nanotube content. This model, depicted by equation (3), depends also on maximum volume fraction $\phi_{\mathrm{m}}$, which is itself related to nanotube aspect ratio [6]. It is important to mention that $\phi$ is replaced by an effective volume fraction of nanoparticles, denoted $\phi_{a}$, with the presence of aggregates within the studied nanofluids, see Ref. [6]. This reference was also mentioned in [2]. Noting that this model was also applied successfully in [7] to predict viscosity enhancement of multi-walled carbon nanotubes aggregated in molten salt.

Such last model could be more appropriate due to flow rate involved in the shell and tube heat exchanger but the deviation with Eq.(2) is very low within the range of nanoparticle content $0.0055-0.278 \%$.

$$
\mu_{n f}=\mu_{b f}\left(1-\frac{\phi}{\phi_{m}}\right)^{-2}
$$

An insight of Figure 1 shows that relative deviation between Eq. (1) and experimental data can attain $79 \%$ for a shear of $1000 \mathrm{~s}^{-1}$ and nanoparticle content of $0.278 \%$ as an example. As some results depend on viscosity value, the use of unappropriated data could potentially 
modify some of the values presented in [1], such as Reynolds number, pressure drop and heat transfer coefficient in particular for nanoparticle content higher than $0.111 \%$.

We finally hope than in future, possible confusion about viscosity models for nanofluid containing nanotubes and nanospheres will be avoided, and that we will see many more demonstration of nanofluid efficiency in industrial plants.

\section{References}

[1] S.M. Hosseini, L. Vafajoo, B.H. Salman, Performance of CNT-water nanofluid as coolant fluid in shell and tube intercooler of a LPG absorber tower, International Journal of Heat and Mass Transfer 102 (2016) 45-53.

[2] S. Halelfadl, T. Maré, P. Estellé, Efficiency of carbon nanotubes water based nanofluids as coolants, Experimental Thermal and Fluid Science, 53 (2014) 104-110.

[3] P. Estellé, S. Halefadl, T. Maré, Thermal conductivity of CNT water based nanofluids: Experimental trends and models overview, Journal of Thermal Engineering 1(2) (2015) 381390.

[4] X. Wang, X. Xu, S.U.S. Choi, Thermal conductivity of nanoparticle-fluid mixture, Journal of Thermophysics - Heat Transfer 13 (4) (1999) 474-480.

[5] S.E.B. Maïga, S.J. Palm, C.T. Nguyen, G. Roy, N. Galanis, Heat transfer enhancement by using nanofluids in forced convection flows, International Journal of Heat and Fluid Flow 26 (2005) 530-546.

[6] S. Halelfadl, P. Estellé, B. Aladag, N. Doner, T. Maré, Viscosity of carbon nanotubes water-based nanofluids: Influence of concentration and temperature, International Journal of Thermal Science 71 (2013) 111-117.

[7] P. Estellé, Comment on "Viscosity measurements of multi-walled carbon nanotubes-based high temperature nanofluids", Materials Letters 138(1) (2015) 162-163.

\section{Figure Caption}

Figure 1. Relative viscosity of CNT water-based nanofluids against shear rate and nanoparticle volume fraction - comparison between experimental data and equation (1). 


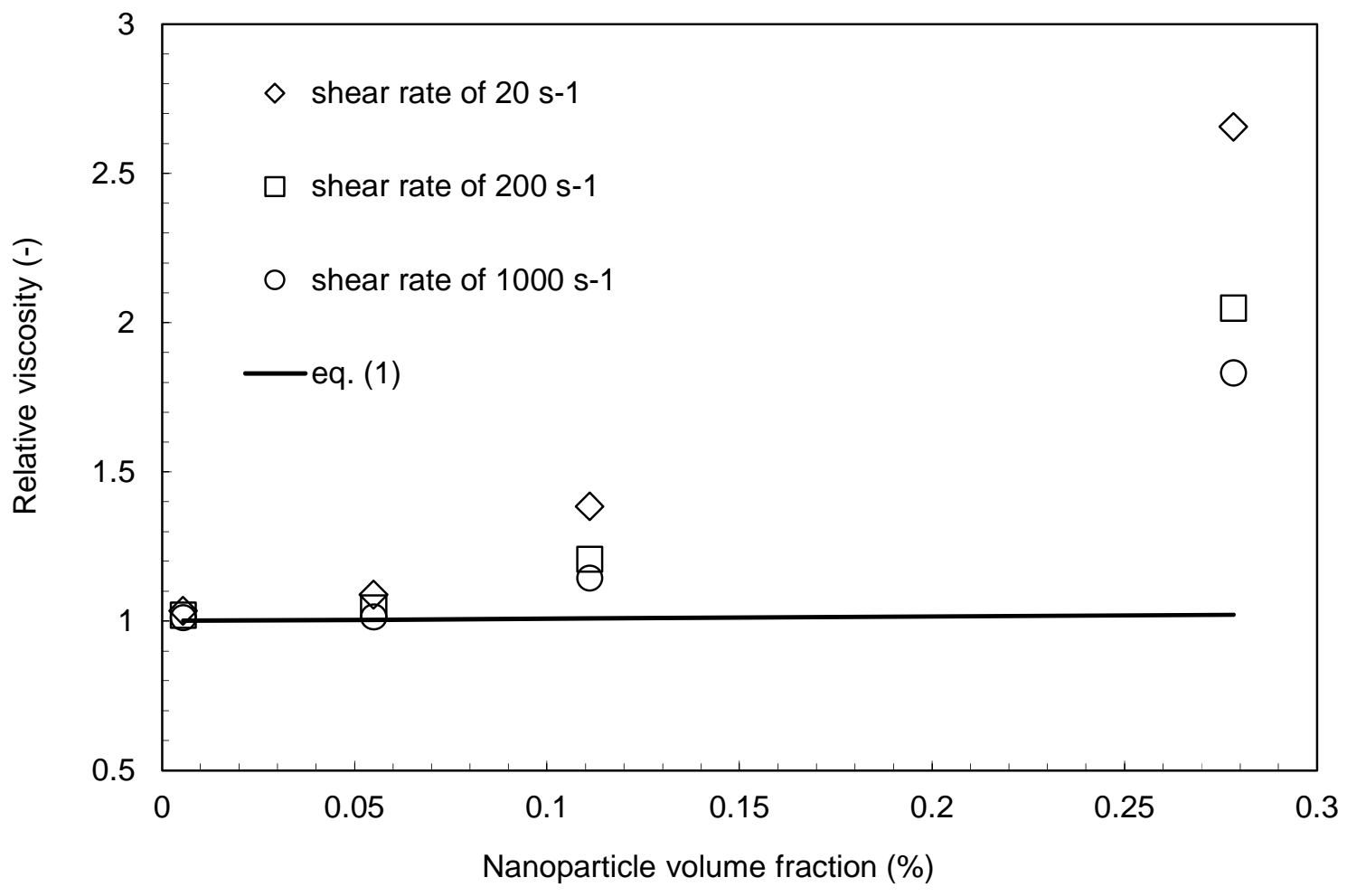

Figure 1. Relative viscosity of CNT water-based nanofluids against shear rate and nanoparticle volume fraction - comparison between experimental data and equation (1). 